Educational Research for Social Change (ERSC)

Volume 8 No. 1, April 2019

pp. 1-13

ersc.nmmu.ac.za

ISSN: 2221-4070

\title{
Rudy and Me: A Man and Dog's Joint Exploration of Their Neighbourhood and Implications for the Transformation of Schooling and Education Research
}

\author{
James A. Bernauer \\ Robert Morris University \\ Pittsburgh, Pennsylvania (USA) \\ bernauer@rmu.edu
}

\section{Abstract}

\begin{abstract}
If we begin with the premise that learning opportunities are not confined to classrooms, then we open up a new way of thinking about education. Most research in qualitative inquiry explores humans and their complexity, based on interviews and observations. However, if we shift our focus to the context itself and, more specifically, to the objects that we see and experience in the world around us, these sights and experiences can be incorporated more fully into the ever developing and deepening reflective memories that connect our present to our past. In this article, I used daily walks with Rudy, our family beagle, as a field of data that could transform the commonplace sensory experience of objects into new perspectives for education and education research. While the human explorer in this study focused on the past, current, and future meanings of objects encountered during the fall and winter of 2017, his canine collaborator focused on everything sensory. As it turned out, Rudy enlarged the experiences and appreciations of the human because dogs, like children, are more concerned with the present than with memories of the past or concerns about the future.
\end{abstract}

Keywords: assimilation, accommodation, education paradigm, mindset, objects, tacit knowledge

\section{Copyright: (C) 2019 James A. Bernauer}

This is an open access article distributed under the terms of the Creative Commons Attribution NonCommercial License, which permits unrestricted non-commercial use, distribution, and reproduction in any medium, provided the original author and source are credited.

Please reference as: Bernauer, J.A. (2019). Rudy and Me: A Man and Dog's Joint Exploration of Their Neighbourhood and Implications for the Transformation of Schooling and Education Research. Educational Research for Social Change, 8(1), 1-13. http://dx.doi.org/10.17159/22214070/2018/v8i1a1

Having been trained in quantitative methodology during my graduate years, I dutifully looked askance at those faculty members who, rather than focus on variables and quantitative methodology, explored obscure things like culture and other "soft" variables, using qualitative methods. I have since come to see the central role that qualitative inquiry plays in learning and schooling because, for education to be worthwhile, it should be a door that encourages us to appreciate the vast time and space that 
surround us, and which is rife with adventurous learning opportunities. This sea change in perspective was facilitated by my writing about the transformation of "methodological identity" that I experienced regarding my growing awareness that worthwhile investigations of anything living (especially humans) simply could not be undertaken, based on a mindset that relegated everything considered nonscientific to the margins (see Bernauer, 2012). I now recognise the virtually limitless opportunities for new discoveries, and have embarked on my own journey with more of a growth than a fixed mindset (Dweck, 2008). However, I still vastly underappreciated the role of artefacts or objects because they always seemed to play the role of simple add-ons to interviews and observations of human participants. I fully concur with Mitchell (2011) that "what counts as evidence in social research has often relied on the analysis of responses in interviews, focus groups, documents and surveys" ( $p$. 35). Mitchell (2011) pointed out that objects and photographs go hand-in-hand. Although objects can't speak to us in our standard spoken language, I have found on my walks with our dog, Rudy, that I now notice things in the physical inanimate world that sometimes speak loudly and clearly and, at other times, seem to whisper about what they have seen and heard during their lives among humans.

While every picture and the object it portrays tells a story, the story differs in relationship to the meaning that each individual learner constructs consciously or unconsciously from this object or picture. I have included a few of the pictures that I took when walking with Rudy during the fall and winter of 2017. Of course, the construction of meaning is a very personal and individual matter but, as social beings, we feel compelled to share the meanings that we have constructed hoping that others will also find meaning in what we share with them-perhaps this is what really constitutes generalisability or transferability. The pictures I have included in this article now have special meaning to me, and I hope that readers also come to discern meaning-especially in terms of implications for how we might transform schooling into a more adventurous experience.

\section{Transforming the Education Paradigm}

Before we can transform practice, we must first consider the perspectives or paradigms underlying much of schooling. Considering the role that testing and grades exert on teaching and schooling, it is no wonder that lecturing and behavioural learning theory continue to thrive. In opposition to earning good grades by successfully passing tests is the notion that a much nobler purpose of education is to create lifetime-learning adventurers whose classroom is the entire world, rather than a room in a brick building. Freire (1993) perhaps said it best when he discussed how dialogue versus "transferrals of information" can liberate education, especially when "the teacher is no longer merely the-one-whoteaches, but one who is himself taught in dialogue with the students, who in turn while being taught also teach" (p. 61). Even more radical is the notion that teaching might be designed to inspire individual and social learning-not only in classrooms but also in our homes, workplaces, neighbourhoods, and wherever else we find ourselves.

Prior to starting our "daily walks," I would like to offer a brief overview of how we might further revisualise what teaching and learning is all about. For me (and I assume for many others), it depends on where we are in our life's journey. When I was in the primary and secondary levels, as well as in college, I imagine retrospectively that learning equalled schooling. Now, many years later, while appreciating that this prior schooling may have provided a platform for learning, I think that schooling exerted constraints on my ongoing learning. These constraints can probably best be captured by using Dweck's (2008) terminology of a "fixed mindset" where everything about learning is about limits and boundaries, while the antithesis of this fixed mindset is a "growth mindset" where learning can grow via "application and experience" (p. 7). While Dweck (2008) was concerned primarily about individual mindsets as a function of personal choice, and offered the opportunity for individuals to transition from a fixed to a growth mindset, I think it is also important to think about the extent to which formal schooling may have fostered an ongoing belief that learning is limited to schooling. The two contrasting 
mindset perspectives portend dramatically different perspectives in terms of whether we remain on this schooling "platform" or if we are able to launch ourselves into the world of continual learning. I also suggest that knowledge of these two differing mindsets should guide how and what we investigate as educational researchers.

Firmly on the side of a growth mindset, Martin (2010) described the central value of both external and internal "wandering" for learning, and bemoaned the fact that modern education is too mechanical and that the intangible, but critically important, characteristics such as insight and identity are ignored. Martin (2010) described external wandering by tracing the history of Irish monks who "crossed the seas to Europe from the sixth century onward" (p. 19), and internal wandering in terms of the teachings of St. Augustine and St. Patrick, and makes the case that wandering can occur in the mind as well as in travels. Sadly, Martin (2010) believed that "the western world in this first decade of the twenty-first century is sleeping 'under sorrow' and that this applies particularly to education" (p. 79). I attribute this sorrow primarily to artificial strictures on learning such as tests and grades that result in equating the spirit of genuine learning with schooling.

I believe that "under sorrow" also applies to me personally because my own schooling experience, based on personal reflection, fits with a fixed mindset and a lack of both internal and external wandering. Rather, in mathematical terms, it was the case that, indeed, learning = schooling. It was rare when learning opportunities were identified or encouraged that connected me to the outside world beyond the walls of the classroom. Unfortunately, even in later years in my doctoral programme, I found myself in an excellent but rationalistic, quantitative culture where all things qualitative were looked down upon or merely tolerated as being less rigorous than the rational (fixed?) mindset. Ironically, it was only when I found myself teaching at university level, and inherited a qualitative research course in addition to my quantitative methods courses, that I began to see that life and learning simply could not be wedged into the rationalistic paradigm (see Guba, 1981). While I can now say that I identify with the naturalistic paradigm, prior to this current inquiry regarding objects, I placed these objects at the bottom rung of intellectual data sources. However, after becoming sensitised to the power of objects in our environment, my wanderings with Rudy have become immensely enriched, and it is these wanderings with Rudy that I describe next.

\section{Rudy}

Snoopy (our first beagle) died in March 2014. Snoopy developed cancer and our veterinarian carefully and tenderly injected a lethal dose as Snoopy lay on our living room floor with my wife, my son, and me caressing him. My son carried him outside, wrapped in his favourite blanket, and we buried him in our backyard marked with a plaque that I am looking at from my study as I write this article. It is this plaque that brought Snoopy to mind-my first recognition of the power of objects! It took us almost two years of mourning to be ready to adopt another dog. Rudy (our current beagle) was born in November 2015, and we welcomed him into our home in January 2016. Rudy, just like Snoopy, is a tricoloured beagle-black, white, and tan-and, although we will never forget Snoopy, Rudy has indeed worked his way into our hearts. It was our walks together every day that afforded me the opportunity to see objects in our neighbourhood as something more than "just objects" but, rather, as harbingers of deeper meaning. I also found that Rudy's natural inquisitiveness led me to places and things that I would not normally have experienced. This picture (Image 1) was taken as snow began to fall and our community began to use salt on the roads. The booties are to protect his feet from the salt and the burning it can cause-and so, we begin our walks together! 
Image 1: Rudy

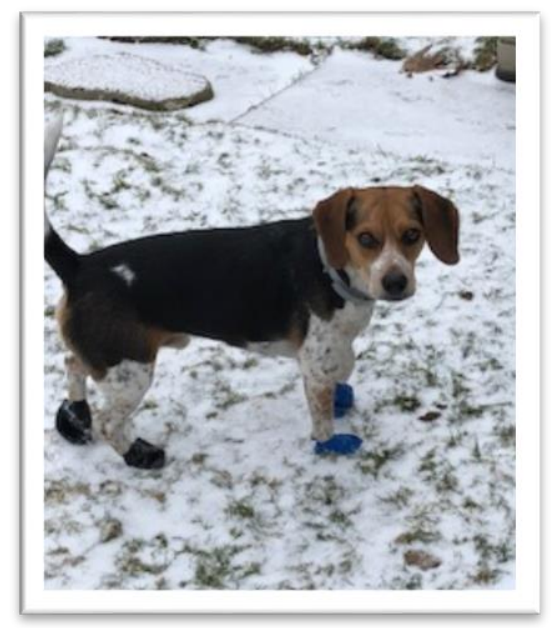

\section{Fall}

As we walked this morning, I noticed how Rudy resembles the colours of the fallen leaves on the ground. However, he also seems to bring out the colours in the leaves as he walks before me while stopping periodically and revealing bright yellow and burnt-orange colours. Perhaps I was in a philosophical mood today because this array of colours reminded me that my perceptions and conceptions of truth are not as black-and-white as they used to be, but a wonderful array of colours. Rudy also exhibits an exuberant happiness when we turn to go back home-running in circles, grabbing sticks, nipping gently on my pants. I felt that he is happy to be heading back home just as we humans feel when we return home after a journey. The sniffing, browsing, and utter joy running and playing in the leaves as we near home and wanting me to join in-is there any better lesson to learn?

We saw an old playhouse (Image 2) today that parents built for their children when they were younger, although this playhouse is no longer used because the children have now grown up and moved away. I wondered aloud if, perhaps, the playhouse remains in their yard simply because it requires effort to dismantle it and haul it away. Or, perhaps there is reluctance to part with the memories of long-ago childhoods.

\section{Image 2: Unused Playhouse}

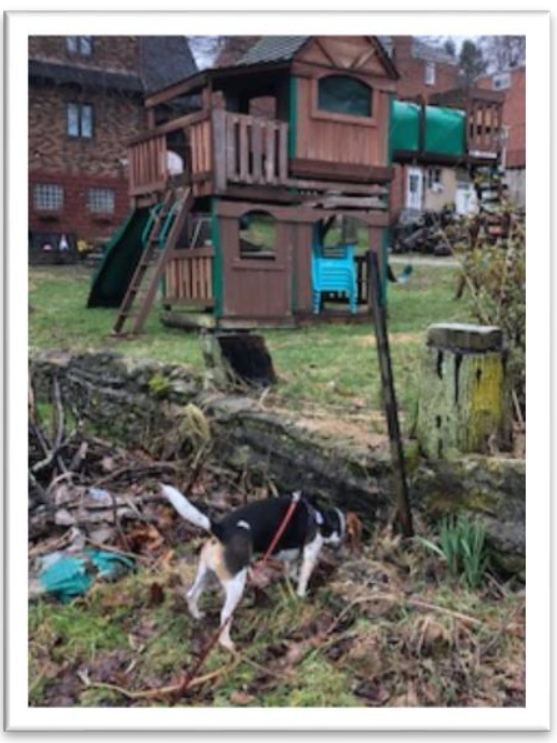


While we did not have a playhouse in our yard, we did have a swing set that we kept for several years after our son had outgrown it because of wanting to retain precious memories of his childhood. The memory of that swing set now reminds me that there must be a balance in our lives among valuing the past, living in the present, and envisioning our futures.

As Halloween arrives, Rudy is both afraid and curious of children he encounters in different costumes and masks, and the realisation struck me that this is much like us when we confront those who differ from us. Given that Rudy is not quite two years old, he hopefully has many more Halloweens ahead of him to learn about this curious holiday. I suppose that autumn is a natural time to think about mortality and the seasons of our lives-where we have been, where we are now, and where we hope to be someday. Of course, Rudy seems to have a continuous "now" because, while he recognises things and people from the past, he is most concerned about exploring the present and apparently has no concern for the future. As he selectively grazes on grass at different points of our daily walk, I can't help but wonder what criteria he uses to decide whether to eat a particular grass or to walk past it without a glance; however, he seems quite certain about what grass is good for him. While I assume that his decisions are based on instinct, it reminds me of the need to be open to what life brings and, also, that we must learn to trust our own instincts about what we should or should not do while heeding James Conant's (n.d.) advice "Behold the turtle. He makes progress only when he sticks his neck out."

As the trees continue to shed their leaves, anticipating the advent of winter, some leaves seem to hang stubbornly onto the branches-perhaps like those of us who recognise the fragility of life and its short duration, and try to now make up for time lost by wringing out as much meaning and joy as we can. On the trail where we sometimes walk, the fallen leaves seem to be predominantly yellow at times, and remind me of the Wizard of $\mathrm{Oz}$ and the path to the Emerald City. For Christians, it also is a reminder of Palm Sunday when people put palm branches on the road as Jesus travelled to Jerusalem. While the nature or nurture controversy may continue, opening our eyes to nature can sometimes simply take your breath away!

Rudy's joy as we started our walk this morning caused me to reflect about the inevitable decline of all of us. Rudy just turned two years old about a week ago, but he is already 14 years old in human years. As we walked past old houses that are in disrepair, with porches that show signs of rot and windows and roofs that are sagging, I realised that their decline is inevitable unless they are renewed by human intervention. It made me think that we too can be renewed in different ways (exercise, meditation, prayer, vacations, etc.) but, unlike houses that are renovated and last more than 100 years, most of us will not reach that age. As I looked at those houses, I imagined stories of the people who once lived in them, which took me into another time-quite a marvel is our imagination!

Rain leaves puddles in the hollows in our neighbourhood streets that look like miniature lakes (that Rudy often laps up) and, today, I saw a little leaf blow into a puddle, bravely launch itself across the "lake," and then return to shore. It struck me that this seems to be the case with us as we travel through life, and sometimes need to "relaunch" ourselves into new places and embark on new adventures to live and learn. But then, we inevitably feel a deep-seated need to return home to our safe harbour. I have found that when back in "harbour," I can reflect on my new experiences from a different perspective and try to assess what I have learned and whether I should stay with it or should try something different. Isn't it amazing that the "ordinary" things that we encounter in daily life hold such lessons? As Rosenblum (2007) asked, "how can a rock, the quintessential physical object, be metaphysical? How can a stone sing? Where does nature stop and culture begin?" (p. 254). 
One of the challenges I confronted today was a cold rain and trying to hold an umbrella (whose utility as a portable roof is too often taken for granted) and dog leash while simultaneously answering a cell phone call. Of course, our ancestors never had to deal with intrusions of this type before the invention of modern technology that allows instantaneous Internet access as well as the use of an unlimited array of apps to do everything from losing weight to monitoring our home security system. Of course, we cannot forget about taking pictures with our phone-including for this article! As we walked together, exploring our neighbourhood and beyond, I reflected that the digital world seems to offer both good and not-so-good benefits. Is the cell phone primarily an object, or has it become a hybrid person that now serves as our primary companion? Should we allow our walks to become yet another extension of always being connected? On the other hand, who can deny the unbelievable adventures we can have simply by exploring the almost limitless potential of the Internet? A bit of a dilemma, it seems! Rudy's fur rose as we went along an alley and saw an overturned garbage can at which he began to growl. Don't we also sometimes anticipate fear and anxiety and then transfer this to unsuspecting "garbage cans" that turn out to be individuals who mean no harm?

We had a brief snow dusting today and came across chairs with cushions (Image 3 ) that were left outdoors and caught by the early snow. Not long ago, these chairs held people who probably talked about common events and concerns - perhaps with a glass of wine in hand. The chairs serve as vestiges of the warmer and brighter days of summer that have now ended. With us too, is it not the case that the times of our lives sometimes seem to change abruptly and other times, subtly, from wellness to sickness, no money problems to major issues, friendships to animosity, and excitement to dullness? As we walk and look at things in our neighbourhood there is an almost human dimension to them because they are, or were once, part of the fabric of individual and family life.

Image 3: Abandoned Chairs

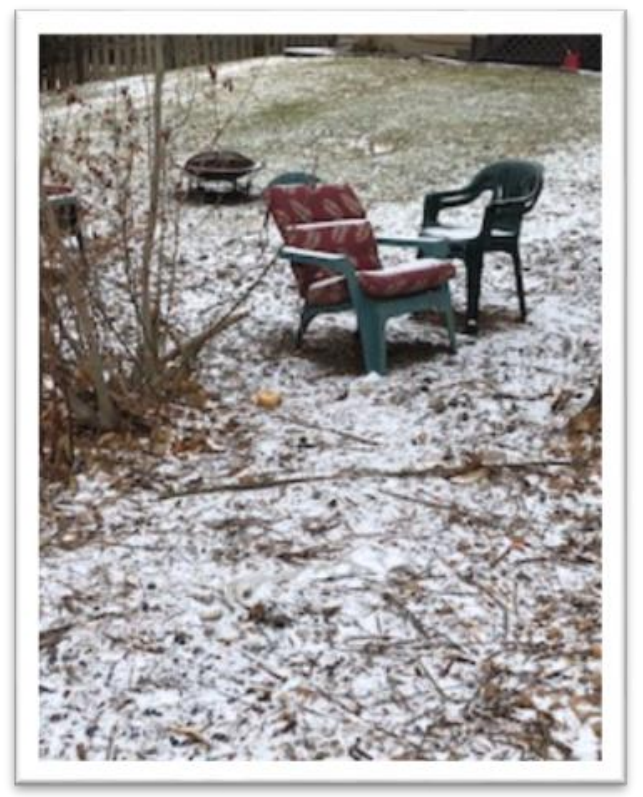

Old garages that are no longer used to park automobiles strike me as dwellings that probably hold memories of not only cars but as hideouts for generations of children who played in neighbourhood games-or perhaps the garages served as places of solitude when family members got angry with each other. Who built these garages, and what tools did they use? There appear to be so many layers of living and experiences that move along with each passing year as old families leave and new families move into our neighbourhood. There are so many vestiges of what once was, and whose memories are now forever stored in the bricks and wood and perhaps also in people's faraway looks as they remember happier times in their lives, and where memories become mellowed just like wine. 
Benches are places that invite conversation either casual among train passengers, or perhaps deeper conversations among people who regularly sit on park benches. In our case, an old bench still stands where a train used to pass through the area but now has become a walking trail for people and dogs (see Image 4). I find myself pondering how many conversations have taken place on this bench during the past 50 years. These conversations may have included parents talking about their children, dog owners about the quirks of their pets, teenagers trying to get away from parents so that they can begin the necessary yet painful pursuit of their own identity, and those recently diagnosed with a major illness. If only benches, garages, and houses could speak.

\section{Image 4: Bench}

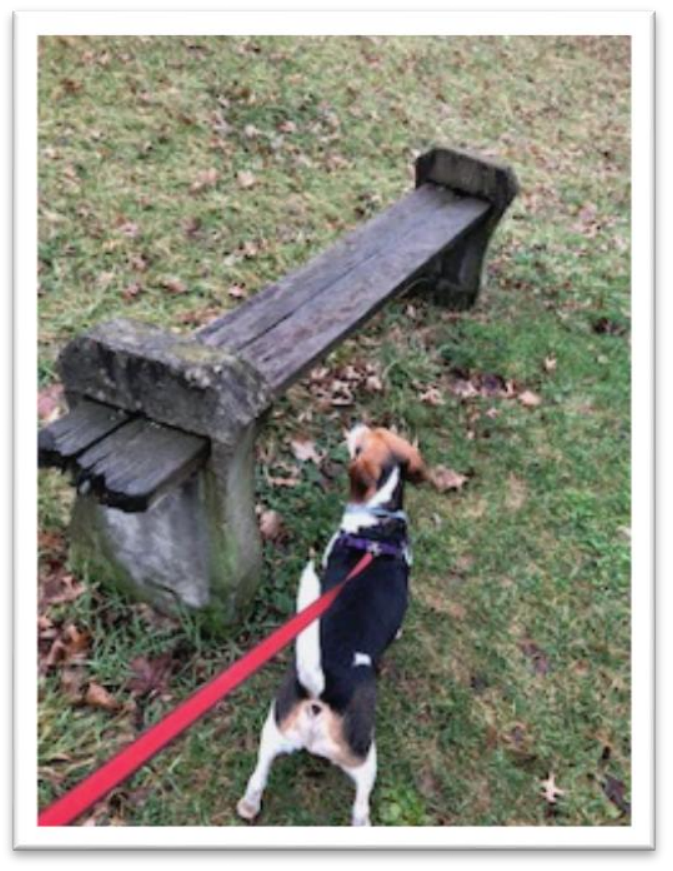

\section{Winter}

Although winter only officially begins around December 21st here, it is the celebration of Thanksgiving in November that seems to signal in our minds that a new season has begun. Based on our walks in the fall, with eyes open for the significance of objects, I now seem to have a new awareness of small spaces in city settings. Beagles like Rudy love to run and hunt and I wonder whether it is cruel to own a Beagle in the city. Then, I look at how Rudy exploits the small spaces of grass that are interspersed with new patches of snow-running, jumping, playing, sniffing. Maybe we too need to learn to be content with our own small spaces in life and to exploit the opportunities they offer if only we take the time to look - there are so many opportunities to learn all around us that revolve around anthropology, history, mathematics, religion, science, and a host of other areas.

We also observe old discarded car tires. While there are not as many as in prior years with the advent of a new commitment to recycle paper, metal, glass, and rubber, I vividly remember rolling tires in childhood as my friends and I imagined that we were driving fast sports cars through the alleys. I tried to resurrect this with my own son when he was young but with no success - I guess the era of tire rolling has ended. We came upon an old and crumbling walled-in area near a walking path in somebody's yard-were there swings or a sliding board there at one time? Did parents play ball with their children? This marker of the past like, so many others, will eventually disappear but somewhere, perhaps even in another part of the world, somebody may remember with a smile the days that were spent simply having fun and enjoying the warmth of the sun or even the cold of winter. 
Another phenomenon that sometimes appears as we walk along are pumpkins that were displayed at Halloween in October, and are still holding on although most are in a state of decay. The pumpkins are now around garbage cans, discarded to make way for Christmas as new decorations and lights start adorning yards. Rudy sniffs at them cautiously, not certain if the pumpkins that have been carved with eyes and mouths are some type of living being. I can feel the uncertainty and the balance and anticipation between Thanksgiving and Christmas as these pumpkins somehow try and pull us back to fall and a warmer time. Cracks in walls, houses, and sidewalks seem to be more visible since vegetation has thinned. These signs of the invisible influences of pressure, gravity, and time remind me of the same "cracks" that are happening in our selves. However, as Christmas decorations start becoming visible at different houses, they also begin to buoy our spirits-objects convey not only signs and signals but also emotions!

Today, I picked up a small evergreen branch and several pinecones that had fallen from a tree in front of our local elementary school. It struck me that these cones are a free and environmentally wise way to decorate for Christmas, rather than the plastic and electric accoutrements that we buy. Rudy found the cones just the right size to put in his mouth and toss into the air, which is his way of inviting me to play with him-both dog and man found a treasure! As we continued to walk around our neighbourhood where the houses were built between the early 1900s to the 1930s (old, by American standards), I reflected that if we had placed time-lapse cameras on these houses and street corners, we would now have a wonderful visual display that would exhibit the progression of change. These changes would reflect environmental changes due to decay and weather, and also the choices of the individuals who lived in these houses, sat on benches, or played on swing sets. As Christmas decorations increased on houses and on street corners, I thought how wonderful it would be to be able to look back on such photographed changes; they would offer us an opportunity to reexamine what we were about, culturally and individually, as time made its inexorable marks on our world-and what learning opportunities would be available to our children!

As the days go by, we come across more fallen trees due to heavy snows on our walking trail where trains had once run, and which now serves as an admirable place for both dogs and people to exercise. These trees look like dismembered human limbs and, while some are relatively healthy, others are filled with decay just like some of the houses that we see. How fortunate we are to have bodies that, while certainly mortal, have such marvellous recuperative capabilities-as well as medical science to help the healing process. It is now suddenly Christmas Eve and decorations of all types are everywhere and, while some seem to simply have been displayed as merely a routine exercise, it is clear that other decorations required much personal attention. Christmas with family dinners and the warmth of homes spurs long-term memories but these would not be complete without the surrounding context that objects provide. However, as Christmas rapidly recedes in time, the Christmas decorations and lights that were everywhere and added to the excitement during the last few weeks prior to Christmas are now fewer and fewer as Christmas trees and wreaths can be seen discarded and waiting for garbage pickup - just like the pumpkins. While Rudy seemed to enjoy all the different displays he came upon, he did not exhibit the letdown that people often experience as the merriment and anticipation of Christmas and New Year's Day become distant memories.

It is now mid-January, and Rudy and I took a walk through a local cemetery and I found myself immersed in looking at the ages of husbands and wives when they died. I wondered what these individuals were like, and what were the joys and sorrows that they experienced? Meanwhile, Rudy was mostly interested in yet another adventure where new sights and scents abound and, as usual, his exuberance was quite noticeable! There is a section of this cemetery where soldiers who fought for the Union Army in the American Civil War are buried. As I looked and reflected on the lives of these soldiers and the war that they fought in, we came across a tombstone that simply read "Soldier" whose identity was apparently never determined. This tombstone, together with those that displayed "KIA" 
(killed in action), evoked deep emotions because Rudy and I were alone in this final resting place for these soldiers (Image 5).

Image 5: Civil War Monument

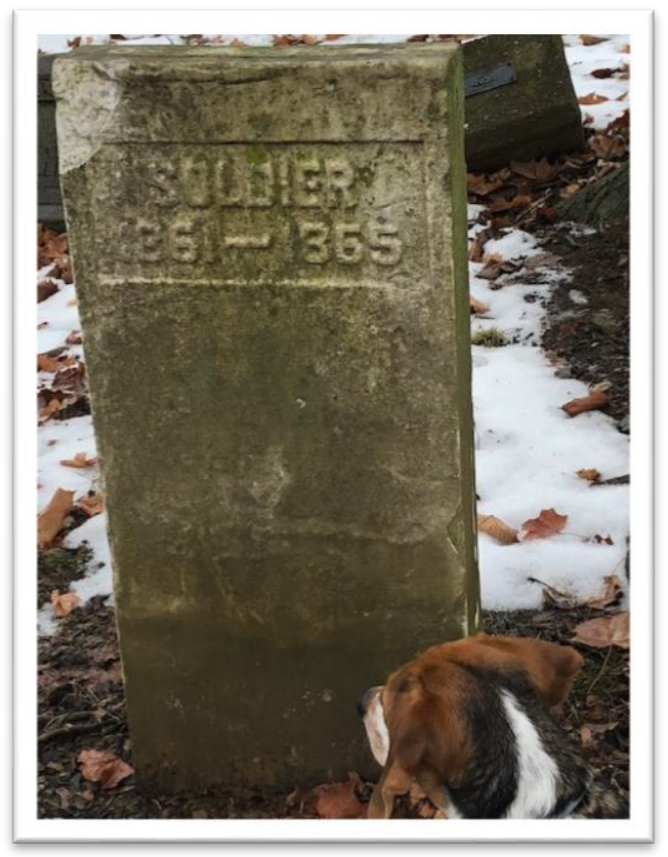

It is now late January and, although a lot of snow fell during December and early January, I marvelled at the snatches of snow that we came across after about two weeks of no new snow-why do these particular small patches of snow survive longer than others? Of course, science could probably offer an explanation based on the position of the sun relative to the earth, shade caused by trees, and other variables; however, all we saw today were brave little white clumps trying to stay alive to remind us how they blanketed our entire landscape just two weeks ago. Isn't it also true that we are constantly on a search for the unique-the outlier, whether in art or even a potential spouse? Statistics, on the other hand, are based primarily on averages and using all available data in order to generalise findings in a context-less environment. How sad the life of those whose lives are "average" and not filled with the adventure and colours all around us, even if it is winter. How sad that we too often allow ourselves to forget the wonder of childhood or of the sense of adventure that seems to be ever present in Rudy. Oh, that our schools would foster this kind of continual wonder!

As February comes and goes, the patches of snow continue to melt, and then be replaced by new snow. Rudy works hard to discover the kind of grass that he finds enjoyable to eat, although his human partner can still see no discernible differences among them. I do notice, however, the permanence of the names of companies that no longer exist-etched into everything from sewer lids to the walls of old buildings. As the first hint of spring begins to show, with some brave little flowers poking through traces of snow, permanence amidst change becomes even more apparent. As I continue to observe, and take pictures on occasion as Rudy and I continue our walks, I realise that the objects I have come to know during the past several months will continue to evoke picture memories because they have become a part of the fabric of my life.

\section{Implications for Schooling and Education Research}

As a consequence of my walks with Rudy from fall 2017 to early spring 2018, my eyes have been opened to things in our neighbourhood that offer wonderful opportunities for learning. I have also 
experienced an increased awareness that the objects that surround us serve as windows that allow us to develop deeper understandings of our neighbourhoods and those who live in them.

My most general takeaway from conducting this study is that I concur with Wolcott (1994) about the difference between education and schooling. In his study, Adequate Schools and Inadequate Education: The Life History of a Sneaky Kid, he told us that his participant ("Brad") told him: "I've always liked learning. I just didn't like school" (p. 63). The curiosity to learn is indeed innate and, while we do well in the first few years of schooling to nurture this curiosity, it seems that as the years of formal schooling follow in predictable fashion that the rules of schooling seem to overshadow the adventure of learning. Consequently, by the time graduation from high school arrives, it is with great happiness that students say goodbye to schooling-perhaps, not recognising that opportunities for deep and meaningful learning are just beginning.

While universities seemingly offer a great deal more freedom than experienced in lower schools, students find that there is an almost endless number of courses that they are required to take, and which are often perceived as unconnected to each other. It is also too often the case that students still value good grades as their primary goal rather than engagement with learning and a passion to continue learning. I have come to realise that novelists can often capture the essence of phenomena better than teachers of subject matter can. One of my favourite quotes regarding education is from the novel, The Magic Mountain (Mann, 1981):

One day all the world would realize that our system, which had developed out of the cloister school of the Middle Ages, was a ridiculous bureaucracy and anachronism, that nobody in the world any longer owes his education to his schooling, and that a free and public instruction through lectures, exhibitions, cinematographs, and so forth was vastly to be preferred to any school course. (p. 519)

My only addition to this focus on free and public instruction would be to also capitalise on the world of learning that surrounds us, and that does not require the accumulation of a decade or more of formal schooling.

As Piaget (1954) suggested, there is continuous interplay between assimilating new knowledge that makes sense to us because it fits nicely with our existing understanding versus needing to accommodate new knowledge and understanding that, initially, we fail to comprehend because it conflicts with our existing perceptions. However, where Piaget focused on cognition, individuals also experience the same type of competing forces emotionally, morally, and socially as we allow ourselves to appreciate new ways of learning. And so, as we come to look at the objects that are part of the fabric of our neighbourhoods and world with an open and adventurous mindset, they emulate the art that we admire in museums and can inspire thoughts and feelings that lead us to further learning. Shouldn't this too, be part of our schooling?

Just like art and other forms of learning that are not easily transmitted in terms of language but through literature, music, and theatre, the knowledge that we construct from objects emanates as much from our tacit understanding based on imagination, reflection, intuition, feelings, and apprehensions as it does from a clear propositional understanding (Polanyi, 1958). After we become more aware of what the environment and the objects within this environment offer us in terms of learning, it is not always easy to communicate this learning without pictures and word pictures. However, this type of learning is every bit as important as learning from textbooks. It may be the case that we have lost this appreciation for learning through observation and listening over the years because learning is now seen as the exclusive purview of schools and textbooks. My walks with Rudy have turned that view on 
its head. Appreciations, ideas, and insights garnered with a direct conversation with the world and its objects transcend the scientific model that often underscores school learning with its emphasis on grades and behavioural learning theory.

Learning and schooling can be liberated from economic and social strictures if students are empowered to learn from their environments-even if these environments are impoverished. It is by valuing their experiences and potential and by drawing out from each student what they find meaningful rather than continuously putting in prescribed curricula that meaningful learning can flourish. As Spindler (1987) noted more than 30 years ago when discussing the relationship between schools and the communities where minority students live: "These institutions stem from a conceptual and cultural context that is different from that of the people whose children are in the schools" ( $p$. 163). This cultural context is comprised, in part, by the objects that are found in it and these same objects (both natural and synthetic) can serve as important links to learning. Learning is not context free, but is grounded in an understanding that real learning is constructed by individuals based on their individual, social, and cultural reflections and interactions including with the objects that are an important part of this milieu.

If the purpose of education research is to help transform schooling into education, as Wolcott (1994) suggested, where students are given opportunities to construct their own rich learning, it must become more authentic in terms of how learning actually occurs. Lagemann (2000) traced the history of educational research, and showed us that it has been unduly influenced by a quantitative-scientific mindset and consequent approaches for teaching and testing. This does not mean that quantitative research should be disbanded but, rather, that a genuine rapprochement must be established between quantitative and qualitative approaches where each methodology is matched to the particular phenomenon under investigation (see Gage, 1989). Whereas qualitative research (including the study of objects) is most appropriate for understanding the intimacy and richness of teaching and learning, the methods of quantitative research allow us to understand influences that, while further removed from this intimacy, are appropriate for assessing the possible impact of variables such as expenditures, student-teacher ratios, and other quantitative measures on student learning.

Hutchins (1990) indicated that "we can learn more about another people from their artistic and intellectual productions than we can from all the statistics and data that can ever be collected" (p. 73). While the objects identified in this current study may not be considered especially artistic or intellectual, they do offer genuine insights into the environment in which students live and, therefore, provide a solid basis upon which to construct learning experiences. Learning opportunities abound all around us in our own neighbourhoods if we only take the time to observe and reflect upon them. I reported only a few of the objects I encountered in my wanderings with Rudy and, from these objects, I constructed mostly historical and philosophical meanings - which probably reflects my own interests and predispositions. However, with an "enlightened eye" (Eisner, 1998), it would be quite easy to construct meaning from objects based on anthropological, artistic, biological, economic, engineering, environmental, ethical, mathematical, literary, political, psychological, and sociological perspectives. As Banks (2007) suggested, even photographs might be able to serve as a way to connect students' environments to schooling and engage not only academic learning but also emotional learning (see $p$. 67). Our neighbourhoods offer students and teachers a living laboratory from which to learn and teach. It is time for us to rethink schooling and its relationship to learning - the future of our communities and our world depends on our reconceptualising learning by believing in the untapped potential curiosities and capabilities of our students and connecting them to world in which they live, including the objects that populate and uniquely define them. By doing so, we can transform both schooling and the role that educational researchers can play in this transformation. 


\section{A Final Word About Rudy}

Although Rudy was a conduit for finding and reflecting upon objects in our neighbourhood in relation to education, he is also an integral part of our family. Although some may think that the term "love" should be reserved solely for humans, if love means deep feelings, reciprocal demonstrations of affection, and willing expenditures of time and money, then I can say that we love Rudy. He is a faithful, playful, and affectionate being. Haraway (2008), after discussing both physical and philosophical implications of living with animals (especially dogs), wrote:

It's late afternoon in December, time for my canine and human household to go running together and come back home to cook dinner. It's time to return to the ordinary knots of daily multispecies living in a particular place and time. If I ignore this simple fact, a determined dog's paws will be on my keyboard typing strange codes I may not know how to delete. (p. 300)

This description captures our life with Rudy. I will forever be grateful to him for his companionship, especially on our daily walks where he continues to lead me to new places where I can reflect on the objects that inhabit them.

\section{References}

Banks, M. (2007). Using visual data in qualitative research. Los Angeles, USA: SAGE.

Bernauer, J. A. (2012). The unfolding of methodological identity: An autobiographical study using humor, competing voices, and twists. The Qualitative Report, 17(69), 1-18.

Conant, J. B. (n.d.). James Bryant Conant quotes. Brainy Quote. Retrieved from https://www.brainyquote.com/quotes/james bryant conant 171089

Dweck, C. S. (2008). Mindset: The new psychology of success. New York, USA: Ballantine Books.

Eisner, E. W. (1998). The enlightened eye: Qualitative inquiry and the enhancement of educational practice. Upper Saddle River, USA: Prentice Hall.

Freire, P. (1993). Pedagogy of the oppressed. New York, USA: Continuum.

Gage, N. L. (1989). The paradigm wars and their aftermath. Educational Researcher, 18(7), 4-10.

Guba, E. G. (1981). Criteria for assessing the trustworthiness of naturalistic inquiries. Educational Communication and Technology Journal, 29(2), 75-91.

Haraway, D. J. (2008). When species meet. Minneapolis, USA: University of Minnesota Press.

Hutchins, R. M. (1990). The great conversation. In M. J. Adler (Ed.), Great books of the Western world (pp. 46-73). Chicago, USA: Encyclopedia Britannica.

Lagemann, E. C. (2000). An elusive science: The troubling history of education research. Chicago, USA: University of Chicago Press.

Mann, T. (1981). The magic mountain. New York, USA: Alfred A. Knopf.

Martin, M. (2010) Learning by wandering: An ancient Irish perspective for a digital world. Bern, Switzerland: Peter Lang.

Mitchell, C. (2011). Doing visual research. Los Angeles, USA: SAGE.

Piaget, J. (1954). The construction of reality in the child (M. Cook, Trans.). New York, USA: Basic Books. Polanyi, M. (1958). Personal knowledge. Chicago, USA: University of Chicago Press. 
Rosenblum, N. (2007). Chinese scholars' rocks. In S. Turkle (Ed.), Evocative objects: Things we think with (pp. 253-259). Cambridge, USA: MIT Press.

Spindler, G. D. (1987). Why have minority groups been disadvantaged? In G. D. Spindler (Ed.), Education and cultural process: Anthropological approaches (2nd. ed., pp. 160-171). Prospect Heights, USA: Waveland Press.

Wolcott, H. F. (1994). Transforming qualitative data: Description, analysis, interpretation. Thousand Oaks, USA: SAGE. 